ショナル表示を含めて, SPECT で, 50〜 75\%の狭窄率の 心筋虚血の検出が可能か否かを検討していただきたい。 今後, 心筋イメージングに関する展望を述べると, 心 筋の糖代謝や脂肪酸代謝などの心筋代謝イメージング法 の開発。また，疾患に特異性の高いトレーサの開発が望 まれ，モノクロナール抗体を利用した梗塞心筋イメージ ングにも期待したい.

\section{RI-16 心機能}

座長 林 真（国立循環器病センター）

\section{9. 右室放射能一時間曲線を用いての RVEF 值の算} 出法の検討

\section{聖路加国際病院放射線科 \\ ○鈴木弘和・山口弘次郎 根津正次・大内周信}

従来，当院において右室駆出率 (RVEF)の算出方法と して，初回循環法 (FP) 時にアルチゲート (MUGA) と を組合せて抬張末期像（ED），収縮末期像（ES）とを選 択し各々に可能な限り正確に ROIを囲み, 各々のカウン 卜数より $\mathrm{EF}$ 值を求めてきたししかし今回は,右室内に数 ピクセルの ROI を設定し右室の放射能一時間曲線を求 め,この曲線を解析することにより RVEF 值を求める方 法を検討してみた。結果は僅か10例ではあるが従来法と 比較し有意差はなかった。 $\gamma=0.93 こ の$ 方法を用いるこ とにより，正確な ROI を設定する必要もなく短時間で RVEF 值を求められ，他の検查においても利用できた。

\section{0. 自動 EF 算出における画像処理条件の影響}

\section{一心動態ファントム実験による検討一}

関東逓信病院放射線科

○安藤俊雄・柳 能成

〔目的〕当院で用いている自動 EF 算出法での filtering 等の画像処理に拈いて, EF 算出上の画像前処理の至 適条件を㮩討し，若干の知見を得たので報告した。

[結果] イ. Butter worth filterのオーダにより変動 し,オーダが 8〜10で EF の変動は少ない.

口. Butter worth filter $の$ cut off 周波数を変化させ たとき，高・低位で変動しゃすく，100〜252が最適であ る.

八. phase 処理の cut off のレベルでは 20〜35\%で設 定位とほぼ一致した EF 值を示し，他では変動しやすい， 二. Butter worth filterのオーダ, cut off 周波数, phaseの cut off は個々にEF 算出上に影響を与え,いず れかの条件の変化により EF 值が変動する。

431. マルチゲート法 (Time slicing 方式)における心機
能パラメータの精度とサンプリング間樎

昭和大学藤が丘病院中央放射線部 ○戸田千秋・綿貫孝彦・金子 悟 斉藤 彰・羽生 毅

$\mathrm{R}$ 波同期マルチゲート収集法の time slicing 方式につ いて左室容積曲線を求める場合，不整脈の混入によって $\mathrm{R}-\mathrm{R}$ 間隔の異なったデータが加算されるがそこでサン プリング間隔が, 疾患の種類, 負荷 EF 検査等において心 機能パラメータの精度に与える影響について特に EF， PER，PFRにおいて検討した。負荷時の臨床データ数に 少々不足はあるものの次のようなことがある程度，正常 者，どの疾患についてもあてはまると思われるＥFは， 安静時 10〜 50 msec, 負荷時 10 40 msec, PER とPFR はともに, 安静時 10〜 40 msec, 負荷時 10〜20 msec の範 囲内でサンプリング間隔を決めれば，パラメータの精度 への影萻は少なく十分測定評価可能である。

432. EF 值算出 (平衡法)における LVROI の設定方法 の検討

$$
\begin{aligned}
& \text { 宮㱦市郡医師会病院 } \\
& \text { O竹下晋司・小玉 淳 } \\
& \text { 後藤和道 }- \text { 上村忠男 }
\end{aligned}
$$

EF 值算出 (平衡法)にむいて，LVROIの設定にあた り，左房 (LA)を含んだ大まかな ROIが用いられ精度に 久ける。すなわ方 LAに貯留したRIの量に左右され，被 検者によってはLAの容量に差がみられ，EF值にかな りの影響を与えることになる。この LA の誤差因子をで きるだけカットする目的で，LVROIの設定方法を検討 した。

LVROI を大まかに全体をとる ROI，上部1/3をカット した2/3の ROI，2/3をカットした1/3の ROI の場合につ いて,心血管造影と相関を見た結果, $2 / 30$ ROI が非常に 相関 $(\gamma=0.94)$ が良く，重相関係数 $\mathrm{R}^{2}=1.28$ とほほ心 血管造影と同じ $\mathrm{EF}$ 値を示した。

433. ${ }^{81 \mathrm{~m}} \mathrm{Kr}$ 持続注入法による右室機能評価の基礎的研究 兵庫県姫路循環器病センター

○大谷幸広・紀田 利・高橋政晴 久保田晴元・高橋龍児

〔目的〕右室駆出率 (RVEF) ${ }^{81 \mathrm{~m}} \mathrm{Kr}$ 持続注入法で算 出する場合に問題となる background（BG）処理およ び，投与経路について娭討した。

【対象と方法】対象は正常18例，急性心筋梗塞症54例 を含む119例である、デー夕収集はSwan-Ganzカテーテ ル (12), 正时静脈 (36), 右外頸静脈 (71) より ${ }^{81 \mathrm{~m}} \mathrm{Kr}$ を持続 注入し，マルチゲート法で行った，RVEFは，4種題の 